И. И. Кулакова

Белгород

DOI: 10.15393/j9.art.2011.307

\section{ВЫРАЖЕНИЕ ПРАВОСААВНОГО ВОЗЗРЕНИЯ В РОМАНЕ «В ВОДОВОРОТЕ» А. Ф. ПИСЕМСКОГО}

лексей Феофилактович Писемский в истории русской литературы стоит несколько особняком. И не только известные истории с фельетонами Никиты Безрылова и романом «Взбаламученное море» повинны в этом. Одна из причин такого положения - своеобразие его творческого метода, названного А. А. Григорьевым весьма точно «реализмом воззрений» ${ }^{1}$.

Роману «В водовороте» на специальные исследования не повезло, хотя в известных монографояя, посвященных творчеству А. Ф. Писемского 1870-х годов, о нем обязательно говорится в позитивно-поощрительном тоне.

Писемский - писатель «своеобышный» - именно такая транскрипция слова способна подчеркнуть «необщее выраженье» его лица. Так называет Матрена, мать Лизы, своего зятя Анания Яковлева, героя пьесы «Горькая судьбина», пожалуй, одного из самых значительных драматических произведений Писемского ${ }^{2}$. Самобытность писателя проявилась во всем: во внешности, поведении, взглядах (он никогда не высказывал книжных истин, даже если разделял их!). Об этом много сказано в воспоминаниях П. В. Ан-

\footnotetext{
(С Кулакова И. И., 2011
}

${ }_{1}$ Григорьев А. А. Реализм и идеализм в нашей литературе (По поводу нового издания сочинений Писемского и Тургенева) // Григорьев А. А. Соч.: В 2 т. Т. 2. Статьи. Письма. М.: Худож. лит., 1990. С. 261-279.

${ }^{2}$ Писелский А. Ф. Соч.: В 3 т. М.: ГИХЛ, 1956. Т. 3.С. 481. ненкова «Художник и простой человек», в работах современных исследователей ${ }^{3}$. Но, кроме «диковинок», было в нем то, что составляло основу его жизни, объединяло с русскими классиками, и значительность и ценность чего нельзя отменить - это его семья, жена Екатерина Павловна, урожденная Свиньина, и два сына. Прав В. А. Пьецух, называя Екатерину Павловну Писемскую, «по литературным понятиям», «классической женой» и сетуя, что она мало знакома даже специалистам ${ }^{4}$.

Парадоксальность литературно-эссеистических суждений самого Вячеслава Пьецуха известна и привлекательна, и в Писемском он обнаруживает лишь блестящего собеседника, но никак не писателя, отодвигая его во второй, а то и в третий литературный ряд. Главный его упрек писателю - отсутствие структурированности в художественном воспроизведении реальной действительности, которым грешит, в частности, его антинигилистический роман «Взбаламученное море» ${ }^{5}$. Но этот нашумевший роман, по всей видимости, не может расцениваться как "визитная карточка» Писемского. Произведение является потоком эмоций, и уже поэтому стройности от него ожидать сложно, но оригинальность писательская в нем тоже нашла как сказаться: здесь Писемский явился пред читателями в своем собственном облике и под своим собственным именем открытое «обнажение приема»! - чтобы резюмировать сказанное в романе.

После журнального скандала он переехал в Москву, купил в Борисоглебском переулке дом с участком, где возводил фрлигеля, давая им имена по названиям произведений, на гонорары от которых они строились. Так его «диковинка» проявлялась в жизни.

${ }^{3}$ Анненков П. В. Художник и простой человек. Из воспоминаний об А. Ф. Писемском // Анненков П. В. Литературные воспоминания. М.: Худож. лит., 1983. С. 478-516; Аннинский Л. А. Сломленный: Повесть о Писемском // Аннинский Л. А Три еретика, М.: Книга, 1988; Могилянский А. П. Писемский: Жизнь и творчество. Л.: ЛИО «Редактор», 1991; Плеханов С. Писемский. М.: Мол. гвардия, 1986 (ЖЗЛ).

${ }^{4}$ Пьеиух В. А. Русская тема. О нашей жизни и литературе. М.: Глобулус, 2005. С. 106

5 Там же. С. $103-106$ 
И вот уже больной и как-то сразу постаревший, хотя и всего лишь 55 лет, он пишет И. С. Тургеневу, к которому искренне был привязан в течение всего их знакомства:

Слава Богу, что все более и более раскрывающееся во мне религиозное чувство еще дает некоторое успокоение и подкрепление моей страдающей душе ${ }^{6}$.

Можно, конечно, сказать, что мы имеем дело с обращением к Богу, произошедшим «по случаю»: в связи с тяжелыми обстоятельствами потери сына, болезни, общего состояния "хандры», перманентно переживаемой Писемским. Но в этом, вероятно, и состоит процесс духовного движения, беспрестанно сопутствующего человеку. Л. Н. Толстой «поздней» поры своей деятельности настойчиво подчеркивал, что человеку свойственна «текучесть», изменчивость. В дневнике от 15 марта 1898 года имеется характернейшая для его представлений о человеке запись:

Все движение. Человек сам непрестанно движется, и потому все ему объясняется движением ${ }^{7}$.

В связи с этим следует обратить внимание на слова Писемского из эпистолярного обращения к Тургеневу:

...все более и более раскрывающееся во мне религиозное чувство...

Они не случайны и как будто указывают на то, что истоки, генезис этого чувства можно и нужно искать ранее, что религиозное чувство было свойственно А. Писемскому всегда.

Особенности его писательского дара в том и состояли, что он трезво оценивал и воспроизводил человека в своих художественных творениях, и православное мировоззрение, традиционное для человека его происхождения и воспитания, прямого выражения там как будто бы не находило. Исключение, пожалуй, составляет его драма, вполне обоснованно отнесенная И. Ф. Анненским к жанру трагедии ${ }^{8}$, где на основополагающих для русского человека представ-

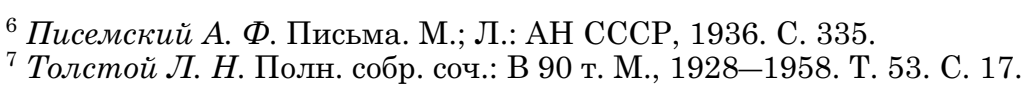

${ }^{8}$ Толстой Л. Н. Полн. собр. соч.: В 90 т. М., 1928-1958. Т. 53. С. 17.
Анненский И. Ф. Три социальных драмы // Анненский И. Ф. Книги отражений. Литературные памятники. М.: Наука, 1979. С. 44-63.
}

лениях о нравственности выстраивается образ главного героя Анания Яковлева, где покаяние его в совершенном преступлении оказывается соединенным с поклоном «миру» и довериел сельскому священнику. Неделимость веры в Бога и доверия батюшке естественны, гармоничны и органичны в потрясенном содеянным злодеянием внутреннем мире Анания и автора народной драмы, художественно воссоздавшей фррагмент из жизни русского человека.

Произведение это нисколько не приукрашивает ни действительность, изображаемую в нем, ни героев, выводимых на сцену. Однако столь же сильно на фоне исключительно реалистического отображения жизни, психологической мотивированности характеров и понимания обстоятельств, в народной драме проявлено чувство единения всех разрозненных персонажей через общие для всех традиции и православную веру. Драма «Горькая судьбина» (1859) и письмо И. С. Тургеневу (1876) - два явных знака, указывающих на возможность выражения православного воззрения в произведениях Писемского.

Роман «В водовороте» (1871) принадлежит книгам, тематически близким к общему для писателей этой поры интересу к «молодому» поколению. Можно с уверенностью сказать, что это более мягкий, нежели «Взбаламученное море», антинигилистический роман. Пожалуй, здесь в полной мере проявились черты Писемского-романиста, и воззрения его тоже нашли здесь закамуфлированное, неявное, но подлежащее восстановлению отображение.

Произведение, созданное неспешно и вдумчиво, дает основания для того, чтобы увидеть, как писатель, отрицая выбранные героями жизненные пути, утверждает невысказанную, но понимаемую и принимаемую им правду жизни, построенной на иных, чем у его героев, принципах и идеалах. В жанровом отношении это не только и, может быть, не столько “смягченная» форма антинигилистического романа, это и классический любовный роман, с его неизбежным «любовным треугольником», в котором полностью отразился «реализм воззрения» автора.

В романе Писемский избирает героев в соответствии со своими реальными представлениями о действительности: здесь нет абсолютных негодяев, кроме поляка Жуквича, 
нет другой интриги «подпольного» действия, кроме сбора средств для страдающих поляков, то есть в пользу того же Жуквича, нет изображения «революционного движения» как такового, а, как это было принято во всей антинигилистической литературе, есть определенный щит из идей для прикрытия мошенничества. В романе Писемского показано лишь искреннее стремление Елены Жиглинской, главной героини, заняться неведомым ей «делом». И в обретении «дела», казалось бы, ей помогает князь Григоров, человек, совершивший своеобразный «уход» из своего круга.

Главный герой романа, князь Григорий Григоров, является человеком, которому тесно в рамках его социальной роли, и он тоже ищет новые идеи и новые фрормы общественного служения.

В письме возлюбленной, девушке, принадлежащей к «новым людям», Елене Жиглинской из Петербурга князь Григоров, рассуждая об официальной и чиновничьей столице, приходит к мысли о необразованности русского человека, даже вышедшего из университета, и предлагает, по его мнению, верный рецепт «повышения умственного и нравственного запаса»:

То, что вошло в нас посредством уха и указки из воспитывающей нас среды, видимо, никуда не годится. Но чем заменить все это, что поставить вместо этого? - Естествознание, мне кажется, лучше всего может дать ответ в этом случае, потому что лучше всего может познакомить человека с самим собой; ибо он, чтобы там ни говорили, прежде всего животное. Высшие его потребности, смею думать, - роскошь, без которой он может и обойтись; доказательством служат дикари, у которых духовного только и есть, что религия да кой-какие песни ${ }^{9}$.

Жиглинская и Григоров начинают вместе читать необходимые для развития материалистического мировоззрения книги - Дарвина, Ренана, Бюхнера, Молешота. Список выразителен и узнаваем по частым упоминаниям литературных пристрастий героев произведений о «новых» людях ${ }^{10}$.

${ }^{9}$ Писелский А. Ф. В водовороте. Курск: Курское книжное издательство, 1959. С 14. Далее приводим цитаты по этому изданию с указанием в скобках страниц. Курсив в цитатах наш.

${ }^{10}$ См., напр.: Мельник В. И. И. А. Гончаров в полемике с этикой позитивизма (к постановке вопроса) // Русская литература. 1990. № 1.
В сюжете романа «В водовороте» важен момент совместного чтения Жиглинской и Григоровым книг с преобладающим физиолого-материалистическим содержанием: автор тем самым дает истолкование любовному чувству, возникшему между князем и нигилисткой. Однако он не искажает последовательности в развитии их чувства, и его этапы довольно традиционны для динамики отношений между мужчиной и женщиной: симпатия, расположенность друг к другу предшествовали совместному чтению; это же подготовило новый этап, завершившийся - уже неизбежно - эротической сценой в гостинице. Русская литература, как правило, была в этом отношении более целомудренна, а Писемский у своих современников слыл за знатока и мастера описаний именно таких «откровенных» эпизодов ${ }^{11}$.

Автор не отказывает ни Елене, ни Григорову в истинном чувстве, которое, несомненно, больше такого «недуга", как простое влечение. Но он не может не противопоставить эту связь «вне закона» отношениям князя Григорова с его женой Лизой. В этом узаконенном сосуществовании уже нет любви-влечения, однако князь не спешит разводиться со своей супругой, более того, он так и не сделает этого, даже когда у Елены родится сын. Григоров «разъедется» с женой, отправив ее в заграничное путешествие с компаньонкой и своим приятелем Миклаковым. Наметившийся в сюжете романа поворот к «параллельной» любовной линии (Лиза Григорова - Миклаков) не получит развития, как не сложится до поры до времени история новых отношений Лизы с влюбленным в нее некогда, во времена ее девичества, бароном Мингером.

По видимости, жена любит Григория, страдает от его измены, но сама вступить на тот же путь не может и не хочет. Что сдерживает ее, оставляя в целомудренной верности своему мужу? Характер, воспитание, понимаемый ею долг данной когда-то клятве? Думается, что Лиза принад-

С. 34-45; Балькова Л. А. Тургенев-читатель. По страницам мемориальной библиотеки. Орел: Издательский дом «Орловская литература и книгоиздательство» («Орлик»), 2005.

${ }_{11}$ Минералов Ю. И. Алексей Феофилактович Писемский // История русской литературы XIX века (40-60-е годы). М.: Высшая школа, 2003. C. 216 . 
лежит тому типу женщин, которые не способны нарушить закон, нормы и правила поведения, принятые в том круге, к которому она относится. Петербургская тетушка князя любит его жену, «княгинюшку», сетует, что у нее нет детей и передает для нее крестик:

...c Геннадия Преподобного, - непременно будут дети...

Что смотришь? Это не для тебя, а для княгинюшки, которая у тебя умная и добрая... гораздо лучше тебя!.. (12)

Григоров же, чувствуя свою вину, пытается ее загладить неуклюже, по-своему поощряя дружбу Лизы и с бароном, и с бывшим журналистом Миклаковым, в то же время он ощущает себя счастливым от сознания того, что чистота их брака со стороны Лизы не нарушена. Ему дорого нечто очень важное, что не превратилось окончательно в их супружестве в развалины, несмотря на историю его непростых, страстных и, казалось бы, бесповоротно сложившихся отношений с другой женщиной. Вот эта-то нерешительность Григорова, порядочного человека, поставленного судьбой перед выбором, и есть, по всей видимости, одна из фрорм выражения авторской точки зрения. Герой не разводится с женой, даже покидая ее, только по причине невозможности разорвать те отношения, которые скреплены венчанием: мужем и женой они стали не перед людьми только, а перед Богом. Физиологическое начало торжествует, но другое, духовное, все-таки не оставляет окончательно. Кажется, что жене Григорова, внешне благопристойной, как и его возлюбленной, но по другой причине, подобное недоступно. Лиза в браке видит лишь форму соединения двоих, даже не понимая этого. Елена - свободная девушка - не принимает никаких старых форм, потому что они ненавистны ей, но совместное бытие требует оформления.

После одного из разговоров, проясняющих жизненные позиции Григорова и Елены - взаимоотношения с родителями, степень возможной независимости женщины в обществе, следует авторский комментарий:

Последний разговор его с Еленой не то чтобы был для него какой-нибудь неожиданностью, - он и прежде еще хорошо знал, что Елена таким образом думает, наконец, сам почти так же думал, - но все-таки мнения ее как-то выворачивали

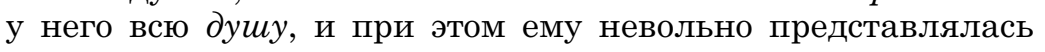

княгиня, как совершенная противоположность Елене: та обыкновенно каждую неделю писала родителям длиннейшие и почтительные письма и каждое почти воскресенье одевалась в одно из лучших платьев своих и ехала в церковь слушать проповедь; все это, пожалуй, было ему немножко смешно видеть, но вместе с тем и отрадно (196).

Потом, в эпилоге, автор сведет на нет противостояние героинь: обе женщины предстанут как заложницы своих антагонистических взглядов, не проявив тех качеств, которых недостает одной и другой, чтобы стать «идеальными» героинями, подобными Татьяне Лариной или Ольге Ильинской.

Именно с князем Григоровым в романе Писемского, как это ни странно, связаны те позитивные нравственные начала, которые писатель мог бы признать отвечающими его этике, близкой этике православного человека. При этом герой Писемского далек от идеала, писатель нисколько не идеализирует его - это составляет отличительную черту всех произведений. Писемскому дорог человек как таковой, и столь же дорога правда о нем. Григоров как человек слаб, как патриот, верный вере своих отцов, вопреки материализму «новых» идей и неожиданно для себя, стоек и принципиален.

В силу необъяснимого чувства привязанности к жене герой не требует развода, и именно он настаивает на крещении ребенка, который родился у Елены. Эта сцена знаменует первые серьезные разногласия между возлюбленными и становится одной из важнейших в романе. Здесь проступают те родовые, патриархальные, основополагающие для князя Григорова ценности, которыми он не может поступиться даже во имя любимой женщины. Елена противница крещения ребенка. В этом обряде она видит и закрепощение личности, и "комедию», в которой не хочет участвовать сама и втягивать в нее только появившееся на свет дитя. Но князя «оставить сына некрещеным, одна мысль эта приводила его в ужас» (218).

Миклаков, которого порой относят к героям, близким автору и к его позиции, приходит на помощь Григорову и находит принимаемые Еленой аргументы в пользу крещения, в частности, он предлагает ей представить выросшего сына, 
обратившегося к ней с претензией такого рода: «На каком основании, маменька, вы отторгнули меня от моей родинь и от моей природной религии?..» (221)

Очень выразительна, думается, такая неделимость понимания родины и родной религии. Православие представляется здесь верой корневой, русской, родной. Это фундамент. На нем зиждутся нравственные устои личности. Писемский уверен, что без этих устоев личность не способна ничего создать, ибо не будет иметь корней. И он же знает, что современный ему человек погружен «в водоворот» мнений, «отрицаний», материалистических, социальных, нигилистических воззрений. Поэтому и выводит в традищиях, пожалуй, почти фельетонных образ священника Иоанна, пришедшего совершать обряд крещения младенца.

Кажется, что образ отца Иоанна нужен Писемскому для того, чтобы значение названия романа, его символика еще раз проявили себя, «манифестируя» главную мысль писателя о всеобщей потере ориентиров на жизненном пути каждого вне сословий и социального статуса. Но противопоставляя этому образованному и читающему священнику сельского батюшку (опять-таки в словесных провокациях Миклакова), писатель как будто говорит, что только в искренности веры можно найти тот якорь, который спасает «в водовороте» «текущего». Лицемерие, ложь, а главное - какая-то странная игра в «поддавки» с "новыми идеями» становятся, по мнению Писемского, разрушителями фондамента искренней веры, а значит, фундамента нравственности и любви, которые должны бы были удерживать современного человека. Двойственность понятий, «широкость» убеждений приводят даже лучших людей к краю пропасти. Результатом такого внутреннего «водоворота», в который попадает положительный герой Писемского, князь Григорий Григоров, становится крах его отношений с любимой женщиной и самоубийство.

В произведении поставлен неизбежный для писателя и всегда своеобразно разрешаемый им «женский вопрос». Кроме Елены Жиглинской и Елизаветы Григоровой, в романе даны образы светской львицы Анны Юрьевны и матери Елены, Елизаветы Петровны. Елена умна и хороша собой, образованна, она, в противовес своей матушке, хочет жить собственным трудом, быть независимой от денег своего возлюбленного. И в ее представлениях о том, как можно осуществить подобное, казалось бы, есть резон. Однако сама жизнь с ее условностями не позволяет героине осуществить в полной мере свои мечты. Кроме того, страстное желание принять участие в большом, настоящем деле сталкивает ее с мошенником Жуквичем, в отказе князя помочь «мнимым бедным девушкам» и столь же мнимому «революционеру, освободителю Польши» она видит эгоизм и ревность и покидает князя. Все его попытки наладить отношения она отвергает даже тогда, когда убеждается, что Жуквич сбежал, ограбив ее.

Непримиримость, какая-то неудержимая тяга к самопожертвованию, не известно во имя каких идеалов, возможно, гордость, перерастающая в гордыню, отталкивают ее от князя, но приводят в супружеские объятия Николая Оглоблина, недалекого, презираемого ею, но искренно полюбившего ее и, в общем-то, доброго светского молодого человека. Тяготы и лишения, которые Елена испытала, подрывают здоровье, и она умирает от чахотки, совсем ненадолго пережив Григория Григорова, который покончил с собой, как только узнал о ее свадьбе.

Она умирает, так и не согласившись на причастие. Миклаков объясняет это ее верностью идеалам, называя Елену «единственной женщиной, которая говорила и поступала так, как думала и чувствовала!» (458). В образе Елены писатель представляет тип женщины-воительницы, в своей гордости отказавшейся от смирения, от любви и от покаяния.

Княгиня Елизавета памяти мужа оставалась верна год. А потом приняла предложение барона Мингера, точно знавшего, что от значительного состояния князя осталась достаточно большая сумма денег. Но вышла она замуж только после того, как «объехала всех близких и именитых родных покойного... и у всех у них испрашивала совета и мнения...» (451). Все были согласны. Княгиня стала баронессой и родила сына. Можно ли ее осудить за это? Вероятно, нет. Но все-таки для нее важно одобрение со стороны тех, кто влиятелен и именит, а не ее собственное сердце! Она, тип женщины-послушницы, по строгому нравственно- 
му счету, повела себя по тем условным правилам, которые создаются людьми в оправдание себя и своих слабостей.

Сколько героинь в романе - столько вариантов возможной реальной развязки «женских историй», и среди них ни одного, отвечающего духу народной православной этики.

Множественность сюжетных линий, завершенность каждой из них не приводят никого из героев к полноте жизненного счастья, подобие же его ожидает тех персонажей, кто «плывет по течению», принимает устоявшиеся лицемерные формы жизни, заменяя ими вековые устои народной нравственности. Человек «почвы», Писемский видел вокруг соблазны богатства, упрощенные отсутствием нравственных барьеров в отношениях между людьми, и, оставаясь верным традициям православной веры, только полагался на то, что водоворот его времени, утихомирившись, позволит человеку вернуться к своим истокам. 